\title{
THE APPROPRIATION OF POLICY CHANGES IN HIGHER EDUCATION BY STUDENTS IN SUB- SAHARAN AFRICA: THE CASE OF THE BACHELOR- MASTER-DOCTORATE REFORM IN BURKINA FASO
}

\author{
Pascal Ramdé ${ }^{1}$ \\ Université Saint Thomas d'Aquin, Burkina Faso \\ Pierre Lapointe \\ Université de Montréal, Canada \\ Martial Dembélé \\ Université de Montréal, Canada
}

\begin{abstract}
Faced with the imperative to adapt to an environment marked by the internationalization of higher education and education policy transfers, universities in French-speaking sub-Saharan African countries adopted in 2006 a new policy called "Bachelor-Master-Doctorate (BMD) reform." Given the importance of the role of the actors in the implementation of a public policy, this study was designed to analyze the appropriation of the BMD reform by students in Burkina Faso. Based on a definition of appropriation consistent with the sociology of public action, we examine how students interpret the BMD reform and their attitude and behavior toward it. Data gathering involved a survey questionnaire administered to 531 students in 2014. The findings show that students have limited knowledge of the reform, and moderate adherence and low commitment to its implementation. In addition, appropriation factors are related to students' sociodemographic characteristics.
\end{abstract}

Keywords: Transfer of Educational Policies; Higher Education; BMD Reform; Appropriation; Students; Burkina Faso

\footnotetext{
${ }^{1}$ Correspondence: USTA, 06 BP 10212 Ouagadougou 06, Burkina Faso; Email: pramde@usta.bf
} 


\section{Introduction}

The historic process of interdependence among nations has intensified since the mid-twentieth century with the establishment of international organizations. It has accelerated over the past thirty years thanks to the development of the internet and information and communication technologies. The education sector is not immune to this globalization trend. Particularly, globalized higher education is an unequal world, with the powerful university systems of economically developed countries at the center and, at the periphery, weak and dependent systems of developing countries (Altbach, 2007). In addition, the globalization of higher education manifests itself in a growing transnational flow, not only of students and researchers, but especially of university policies and reforms. For Steiner-Khamsi (2012), the transfer of policies to developing countries is not necessarily done for reasons of proven efficiency, but sometimes for political and economic reasons.

We believe then that the claim to export educational policies formulated in the West as reference models is a threat to the aspiration of this continent to autonomously define and conduct its educational project. Indeed, as Ki-Zerbo (1992, p. 51) asserts, "we do not develop others, they self-develop" ${ }^{2 "}$. The appropriation of policies from elsewhere by local actors is therefore both a necessity and an attempt to maintain control of their own destiny. The Bachelor-Master-Doctorate (BMD) reform is a manifestation of the globalization of higher education in French-speaking sub-Saharan African countries, since it is the result of a transfer to these countries of the Bologna Process (PB) developed by the European countries in the late 1990s.

This article reports the results of a study designed to assess the degree of appropriation of the BMD reform by local actors in Burkina Faso, in this case, students. This is an emerging field of study in French-speaking sub-Saharan Africa and unexplored in Burkina Faso. Through this research, we aim to contribute to a better understanding of the dynamics of university reforms in this country and to improving their implementation management. The article comprises five sections: (1) the context of the study, including a presentation of the Bologna Process and research on its implementation; (2) the theoretical and conceptual framework chosen, inspired by the sociology of public action; (3) the study methodology based on a questionnaire survey; (4) the results obtained in relation to the three research questions through descriptive and inferential analyses; and, finally, (5) the discussion of these results with regard to similar scientific works.

\section{Context of the Study}

To contextualize the question that triggered this study, we briefly outline the Bologna Process (BP), the BMD reform inspired by it, and the research works that these two university policies have generated. The genesis of the BP was the meeting in May 1998 at La Sorbonne between the ministers of higher education of France, Germany, the United Kingdom and Italy, all then faced with national issues related to management and reforms of higher education (Ravinet, 2009). This ministerial meeting was seen in the European sphere as a lever to justify and undertake local reforms imposed by the need for more effective and attractive education in the context of globalization. Indeed, according to Charlier and Croché (2010, p. 77), it would be "easier to impose a measure on the national scene if it is decided at an international level and therefore applies to a larger territory".

2 Original quote: « On ne développe pas, on se développe. » 
The Sorbonne Declaration, which can be considered the founding document of the $\mathrm{BP}$, clearly outlines the plan to harmonize the architecture of the higher education system by calling upon the other European countries to join in (Allègre, Berlinguer, Blackstone \& Rüttgers, 1998). It was in June 1999 that representatives from 29 European countries gathered in Bologna to discuss the harmonization of higher education training structures in Europe. As a result of their discussions, they adopted the Bologna Declaration (European Ministers of Education, 1999). The Declaration especially refers to the adoption of a restructuring of the training path and a descriptive outline of diplomas, the establishment of a system of transferable credits, the strengthening of the mobility of students, teachers, researchers and administrative staff, and the promotion of cooperation in quality assurance and of the European dimension.

Woldegiorgis, Jonck and Goujon (2015) argue that the content of the reform defined in Bologna in 1999 has evolved with the pace of ministerial meetings. The architecture of a two-cycle system, defined in Bologna, was completed in Prague in 2001 with the inclusion of lifelong learning, and then in Bergen in 2005 with a three-year third cycle. This threecycle model is called LMD or BMD, with reference to end-of-cycle degrees: Licence or Bachelor's degree, Master's degree, Doctorate. In Bergen, the ministers also affirmed the need to give the $\mathrm{BP}$ an external dimension by making it attractive to countries outside Europe. This initiative was supported by UNESCO (Charlier, 2009). In April 2006, the Ministers of the African and Malagasy Council for Higher Education (known by its French acronym, CAMES) ${ }^{3}$ recommended "the reconfiguration of university programs and the organization of universities and schools in the CAMES area according to the BMD model" (CAMES, 2006).

The content of the new education and training system in the CAMES area is specified in the organizational documentation of the two sub-regional bodies (Communauté économique et monétaire des États de l'Afrique centrale ${ }^{4}$, 2006; Union économique et monétaire ouest-africaine $\left.{ }^{5}, 2007\right)$ and in the guide developed by the Association of African Universities (Association des universités africaines, 2008). This new system has many similarities in content with the PB since it is inspired by the latter. The similarities include the two main innovations for the CAMES area: semestrialization and capitalization. The semester became the basic temporal unit, replacing the academic year in the old system. One semester consists of 14 to 16 weeks of teaching and assessment activities. Thus, the bachelor's degree, the master's degree and the doctorate correspond respectively to courses of six, four and six semesters, a university year comprising only two semesters. Capitalization is a pedagogical principle by which a course unit (CU) validated within a study program by a student is recognized for life. Its value is measured in credits; a credit is the workload estimated to be necessary to achieve the CU's objectives, i.e. an average of 20 to 25 hours. One semester requires 30 credits to be valid.

Although there are many similarities between the BMD reform and the BP, it should be noted that the latter has a specific monitoring group (Bologna Follow-up Group) and a systematic monitoring mechanism for its implementation. In addition, the objectives of the BP place greater emphasis on mobility and the European and social dimension of

${ }^{3}$ CAMES includes 19 countries in sub-Saharan Africa, of which 17 (including Burkina Faso) are former French or Belgian colonies where the higher education system is strongly linked to those of the colonizing countries.

${ }^{4}$ Economic and Monetary Community of Central African States

${ }_{5}^{5}$ West African Economic and Monetary Union 
higher education. On the other hand, countries in sub-Saharan Africa do not have a systematic monitoring mechanism through a specific body; nor is there a strong emphasis on promoting sub-Saharan mobility or the social dimension in the reform.

Other important pedagogical and administrative changes in common involve new ways of teaching, evaluating, learning, defining curriculum content and managing and administering higher education structures. Such changes involve all the actors of the institutions of higher education concerned, namely top officials, academic staff (particularly the teachers), administrative staff and the students.

The $\mathrm{PB}$ has been the subject of several studies in Europe, where Mesquita, Fernandes, Pereira, Flores and Filipe Costa (2011) have identified 124 articles published between 2000 and 2011. For example, in research works based on a culturalist approach inspired by the cultures of disciplines (Becher \& Trowler, 2001; Hoffman, Välimaa \& Huusko, 2008) have shown that, in Finland, globally competitive administrative units appear not have been bothered by the reform, while those with a limited and local competitive horizon resisted the BP. In a more recent research report, Crosier and Parvela (2013) note that in the $47 \mathrm{BP}$ signatory countries, "while in general higher education stakeholders who are well informed tend strongly to be engaged and supportive, there is nevertheless widespread and strong resistance to Bologna reforms" (p. 68). This is the same resistance to neoliberal policies (privatization, liberalization of the market) introduced in higher education because, according to the same authors, "in the minds of many European students and academics, a neo-liberal agenda has become associated with the word 'Bologna'” (p. 68).

The implementation of the BMD reform in sub-Saharan Africa has been the subject of several theoretical and critical analyses (Charlier \& Croché, 2012; Charlier, Croché \& Ndoye, 2009; Idiata, 2006; Khelfaoui, 2009; Shawa, 2008). Some authors, apparently taking for granted the principle and necessity of reform for the improvement of higher education in the region, describe their experiences in implementing the BMD system. Others criticize the appropriateness of this change, seeing it as a factor of instability or highlighting its exogenous and post-colonial character.

Some empirical studies on the implementation of the new system have also been conducted, particularly in Burkina Faso (André, 2009), Cameroon (Doh, 2007; Feudjio, 2009; Mngo, 2011; Eta, 2015; Eta et Vubo, 2015) and in Senegal (Diop, 2016; Goudiaby, 2009; Ndior, 2013). The theoretical frameworks of these studies are not always clearly explained by their authors, following a general trend noted by Tight (2004) in research on higher education. The methodological approaches are also varied, but for most of the authors cited, the focus is on the actors and their processes of appropriation of the changes brought about by the BMD reform. Analyzing the relations between public policies and actors, Gabas (2003) stresses the need to identify the relevant actors who really influence the policy, but who are sometimes masked by the institutional or more visible actors upon which the public policy is formally based.

Indeed, even "if states are almost always able to impose reforms, those who are in charge of implementing them can empty them of any substance by keeping intact historically developed practices" (Khelfawi, 2009, p. 16). But most studies on BMD reform in sub-Saharan Africa that take into consideration students among the actors analyze the phases of the policy prior to its implementation; only Diop (2016) analyzes the experience that Senegalese students have of the implementation of the reform. Its results show that in Senegal "the students' assessment of the reform as regards their knowledge of the system, their involvement in its implementation, but also the training content, generally remains 
quite negative" (p. 195) and depends on the contextual variables (curriculum, level of education and university attended). For Burkina Faso, the reform arises in a context of vitality of the student and teacher union movement (Bianchini \& Korbéogo, 2008; Sanou \& Charmillot, 2010; Sory, 2012). It is therefore relevant to question the way in which Burkina Faso's higher education actors, particularly students, take ownership of the changes brought about by the BMD reform: this is the general question that this study seeks to answer.

\section{Theoretical Framework}

In the study of the transfer of public policies, Steiner-Khamsi (2014) distinguishes two streams of analysis: a normative and comparative approach that wants to identify best practices and an analytical approach that studies the conditions of emergence of practices and the impact of their transfer on local policies. The position of this study is more analytical than normative or positivist, putting the actors and their experiences at the heart of the reflection. In this respect, the sociology of public action that considers public policy as a collective construction by actors in contextualized interactions has been fruitful (Datnow \& Park, 2009; Hassenteufel, 2011; Lascoumes \& Le Galès, 2011).

At the heart of this study is the concept of appropriation. According to SalibaCouture (2011), this is an ambiguous and ambivalent concept. It is commonly used in a wide variety of fields such as technology, international relations, psychology and education. In the English-Language literature, according to Baillette and Kimble (2008), the term has been understood in the sense of dispossession of the property of others, of social use or, among structuralists (DeSanctis \& Poole, 1994; Giddens, 1987), as "the way a group uses, adapts and reproduces a structure" (Roux, 2007, p. 126), the structure being what forms and shapes social life. In the French-language literature, the concept is used in two perspectives, as the result of a process (Jacquemot, 2007; Proulx, 2002; Saliba-Couture, 2011) or as the process itself (Bianchi \& Kouloumdjian, 1986; Deniger, 2012; De Vaujany, 2006; Massard, 2007). In the perspective of a process, Deniger (2012) envisions the appropriation of change in education as a process of understanding, adherence and commitment. The definition is summary, but has the advantage of framing more clearly in time a sequence that can be recurrent, by identifying its most important dimensions. In the same perspective, this study defines appropriation as a complex process of interpretations, attitudes and behaviors through which actors respond to change.

\section{Interpretation}

Interpretation can be understood as a process by which one gives meaning to a cognitive object or action (Brewer, 2003). In Max Weber's sociology, comprehension is a central concept, since it is postulated that the human being acts according to his understanding of the world. For Scott and Marshall (2009), interpretation and comprehension are intimately linked, and any act of understanding implies a certain interpretation. It is the cognitive dimension of appropriation that specifies how one understands change and what one knows about it. But interpretation integrates, as a precondition, a process of translation from a literary and sociological point of view.

The sociology of translation (Callon, 1984) has highlighted the importance of interactions between actors to construct new meanings. The sense-giving process is linked to the system of representations of each group of actors, in particular to its cultural referents (Nisbett \& Miyamoto, 2005; Prislin \& Wood, 2005). It should be emphasized, 
however, that interpretation is not limited to the formal content of the policy, but also takes into account all stages of the policy cycle, in this case its implementation.

\section{Attitude}

According to the authors of The Handbook of Attitudes (Albarracin, Johnson, Zanna \& Kumkale, 2005, p. 4), most researchers share the definition of Eagly and Chaiken (1993) that "an attitude is a psychological tendency that is expressed by evaluating a particular entity with some degree of favor or disfavor". For theorists of reasoned action, like Fishbein and Ajzen (2010), attitude derives from beliefs and information. The information resulting from the interpretation of the proposed change is integrated in the other components of the rationality of the individual to arouse in him a favorable disposition (adherence) or unfavorable (rejection) to the change. Attitude therefore represents the affective or evaluative dimension of the appropriation process and informs what the actors think of the change and how they feel about it. An attitude may vary over time (Kruglanski \& Stroebe, 2005), although it is much more stable than an opinion.

The typology of attitudes is not always reduced to binary categories (favorableunfavorable, agreement-disagreement, for-against, acceptance-rejection, ...), but can also be represented on a continuum (such as on Likert scale). In addition to the role of communication and the sociocultural context, Albarracín, Johnson, Zanna, and Kumkale (2005) emphasize the influence of self-perception, beliefs and emotions on the training process and changes of attitude. In contrast, Marsh and Wallace (2005) argue that attitude influences beliefs. Attitude and beliefs therefore influence each other.

\section{Behavior}

Behavior refers to the factual and observable dimension of the appropriation process of change and what actors do with it. A weak or moderate relationship between attitude and behavior has been established by several studies (Fishbein \& Ajzen, 2010; Michelik, 2008) that have shown behavior can be determined by attitude. Conversely, other authors such as cognitive dissonance theorists argue that behavior can also determine attitude (Olson \& Stone, 2005; Vaidis, 2006).

Resistance is the first type of behavior studied with respect to change. In organizational theory, it is "the refusal to accept change and is characterized by behaviors designed to obstruct, hinder or block change" (Bareil, 2008, p. 90). Behavior that is opposed to resistance is "support for change," defined as the alignment of actors with the goals and objectives of change (Meunier, 2010; Orth, 2002).

Resistance and support delineate a continuum of reactions to change. Herscovitch and Meyer (2002) list among possible behaviors: active resistance, passive resistance, conformity, cooperation and active support. Orth's (2002) typology retains active resistance, passive resistance, passive support and active support. In his study of education reform in Québec, Meunier (2010) shows that resistance and support behaviors could be predicted from the study of the phases of concern, but also that "emotional commitment [i.e., attitude] toward change acts as a mediating variable and helps explain more variance in support and resistance behaviors" (p. iv).

\section{Study Questions}

The above approaches to the three dimensions of appropriation highlight its complex and interactive nature, which implies the existence of relationships between the 
identified components. The examination of the appropriation of the BMD reform by the students in Burkina Faso thus aims to answer the following questions:

- How do students in Burkina Faso appropriate the BMD reform?

- Does the appropriation of the reform vary according to the gender, university of affiliation, study program and cohort of the students?

- To what extent are the three dimensions of reform appropriation (interpretations, attitudes, behaviors) related?

\section{Methodology}

This study was carried out in two universities which represent $70 \%$ of the publicsector student population of Burkina Faso: the Université Ouaga 1 Professeur Joseph-KiZerbo (UO1), the oldest in the country and the first to implement the BMD reform, and the Université Norbert Zongo in Koudougou (UK), the latest public university to be created and to implement the reform at the time of data collection. The questionnaire survey conducted from March to April 2014 received the approval of the Multi-Faculty Research Ethics Committee of the University of Montreal and was administered to 531 students. A consent form attached to the questionnaire ensured the voluntary participation of respondents.

Participants. The sample of respondents to the questionnaire includes $34 \%$ females $(\mathrm{n}=181)$ and $66 \%$ males $(\mathrm{n}=349)$, which corresponds to the current makeup of the student population in the public university sector, i.e. 30\% female and 70\% male (Ministry of Higher Education, Scientific Research and Innovation, 2016). Of the respondents, 63\% were from UO1 $(\mathrm{n}=335)$ and $37 \%$ from UK $(\mathrm{n}=196)$. Their distribution by study program is as follows: $13 \%$ in Pure and Applied Sciences/Life and Earth Sciences (PAS/LES), 43\% in Letters, Arts and Communication/Humanities/Legal and Political Sciences (LAC/H/LPS), $28 \%$ in Health Sciences/Technical and Technological Sciences (HS/TTS), and 16\% in Economics and Management/Education $(\mathrm{EM} / \mathrm{Ed})^{6}$. This grouping of training programs draws on Kolb-Biglan's classification (Becher, 1989) in four groups, based on two criteria: the level of paradigmatic development or consensus in the discipline (hard vs soft) and the degree of applicability of the discipline (pure vs applied). Assuming that the year of admission to university corresponds to that of obtaining the end-of-secondary school diploma, and taking as a reference the beginning of the reform implementation in 2009, the distribution of questionnaire respondents by cohort groups is as follows: $8 \%$ for 2001-2008 (before the reform); $72 \%$ for 2009-2011 (the first three cohorts since the implementation of the reform began) and 20\% for 2012-2013 (the two most recent cohorts).

Questionnaire. The 30 questionnaire statements were taken, adapted and complemented from the instruments used by Meunier (2010) on the prediction of resistance behavior of school principals to change in Québec and by Mngo (2011) on the perceptions of the BMD reform among teachers in Cameroon. Although the instruments developed by the two authors are not directly aimed at students, their use is relevant in our study, first of all because they were intended for school actors. Additionally, Mngo's questionnaire (2011) is partly inspired by the 2003 Student Survey on the Acceptance of the Bologna Process (SSABP) developed by Willige (2003); it is therefore adapted to the student population of our survey.

\footnotetext{
${ }^{6}$ The distribution of the student population by field of study is not available for the period.
} 
Table 1. Distribution of students according to their degree of agreement regarding the interpretation of the BMD reform $(n=522)$.

\begin{tabular}{|c|c|c|c|c|c|}
\hline Num. & Items & Disagree & $\begin{array}{c}\text { Somewhat } \\
\text { disagree }\end{array}$ & $\begin{array}{c}\text { Somewhat } \\
\text { agree }\end{array}$ & Agree \\
\hline $\mathrm{E} 2$ & $\begin{array}{l}\text { I know about the } \\
\text { adoption of the Bologna } \\
\text { Process reform by } \\
\text { European countries. }\end{array}$ & $79 \%$ & $6 \%$ & $5 \%$ & $10 \%$ \\
\hline E3 & $\begin{array}{l}\text { I know about the } \\
\text { influence of the } \\
\text { European Bologna } \\
\text { reform on the BMD } \\
\text { reform. }\end{array}$ & $73 \%$ & $10 \%$ & $7 \%$ & $10 \%$ \\
\hline $\mathrm{E} 8$ & $\begin{array}{l}\text { I know about the } \\
\text { usefulness of the } \\
\text { "Diploma Supplement" } \\
\text { foreseen in the BMD } \\
\text { reform. }\end{array}$ & $54 \%$ & $10 \%$ & $12 \%$ & $24 \%$ \\
\hline $\mathrm{E} 1$ & $\begin{array}{l}\text { I know why Burkina } \\
\text { Faso adopted the } \\
\text { reform. }\end{array}$ & $47 \%$ & $9 \%$ & $20 \%$ & $24 \%$ \\
\hline $\mathrm{E} 7$ & $\begin{array}{l}\text { I understand the } \\
\text { organization of training } \\
\text { in course units. }\end{array}$ & $42 \%$ & $13 \%$ & $16 \%$ & $29 \%$ \\
\hline E 10 & $\begin{array}{l}\text { I understand the } \\
\text { implications of this } \\
\text { reform on how to study. }\end{array}$ & $42 \%$ & $13 \%$ & $16 \%$ & $29 \%$ \\
\hline E9 & $\begin{array}{l}\text { I understand the new } \\
\text { organization for } \\
\text { obtaining diplomas in } \\
\text { the BMD reform. }\end{array}$ & $38 \%$ & $12 \%$ & $19 \%$ & $31 \%$ \\
\hline E5 & $\begin{array}{l}\text { I understand how the } \\
\text { BMD credit system } \\
\text { works. }\end{array}$ & $40 \%$ & $9 \%$ & $13 \%$ & $38 \%$ \\
\hline E4 & $\begin{array}{l}\text { I understand the } \\
\text { academic and political } \\
\text { objectives of the reform. }\end{array}$ & $40 \%$ & $8 \%$ & $16 \%$ & $36 \%$ \\
\hline E6 & $\begin{array}{l}\text { I understand } \\
\text { semestrialization in the } \\
\text { BMD reform. }\end{array}$ & $28 \%$ & $7 \%$ & $16 \%$ & $49 \%$ \\
\hline
\end{tabular}

For items relating to interpretation (13) and attitude (6) toward reform, through the cue "Please indicate to what extent the statements below express your point of view by circling the number which best expresses your opinion on the BMD reform," respondents were asked to express their agreement or disagreement using a six-point Likert scale: (1) strongly disagree; (2) disagree; (3) somewhat disagree; (4) somewhat agree; (5) agree; (6) strongly agree. For example, we have the item "I understand how the BMD credit system works" for 'interpretation', or the item "I believe in the merits of the reform" for 'attitude'. For the 11 behavior measurement 
items, participants were asked to "Please indicate to what extent each statement is representative of your behavior by circling the number that expresses it best" by estimating the frequency of the manifestation of the targeted behavior on a four-point Likert scale: (1) not at all; (2) a little; (3) enough; (4) a lot. "I was openly critical of the reform" is an example of a behavior measurement item.

Table 2. Distribution of students according to their degree of agreement on the attitude toward BMD reform $(n=525)$.

\begin{tabular}{|c|c|c|c|c|c|}
\hline Num. & Items & Disagree & $\begin{array}{l}\text { Somewhat } \\
\text { disagree }\end{array}$ & $\begin{array}{l}\text { Somewhat } \\
\text { agree }\end{array}$ & Agree \\
\hline $\mathrm{E} 12$ & $\begin{array}{l}\text { The BMD system is more } \\
\text { flexible and acceptable to me } \\
\text { than the old system. }\end{array}$ & $53 \%$ & $9 \%$ & $15 \%$ & $23 \%$ \\
\hline $\mathrm{E} 18^{\mathrm{a}}$ & $\begin{array}{l}\text { Things would be better without } \\
\text { the reform. }\end{array}$ & $28 \%$ & $15 \%$ & $13 \%$ & $44 \%$ \\
\hline E 15 & $\begin{array}{l}\text { The reform is a good } \\
\text { strategy for higher education } \\
\text { in our country. }\end{array}$ & $48 \%$ & $8 \%$ & $16 \%$ & $28 \%$ \\
\hline E 14 & $\begin{array}{l}\text { I believe in the merits of the } \\
\text { reform. }\end{array}$ & $41 \%$ & $10 \%$ & $18 \%$ & $31 \%$ \\
\hline E11 & $\begin{array}{l}\text { Adopting the BMD which is } \\
\text { like the European Bologna } \\
\text { Process would facilitate } \\
\text { student and faculty } \\
\text { exchanges between Europe } \\
\text { and Burkina Faso. }\end{array}$ & $40 \%$ & $8 \%$ & $18 \%$ & $34 \%$ \\
\hline $\mathrm{E} 16^{\mathrm{a}}$ & $\begin{array}{l}\text { The authorities are making a } \\
\text { mistake by implementing the } \\
\text { reform. }\end{array}$ & $38 \%$ & $16 \%$ & $9 \%$ & $37 \%$ \\
\hline $\mathrm{E} 19^{\mathrm{a}}$ & The reform is unnecessary. & $40 \%$ & $15 \%$ & $8 \%$ & $37 \%$ \\
\hline $\mathrm{E} 17$ & $\begin{array}{l}\text { The BMD reform goals are } \\
\text { important. }\end{array}$ & $23 \%$ & $7 \%$ & $16 \%$ & $54 \%$ \\
\hline E13 & $\begin{array}{l}\text { The UEMOA Credit } \\
\text { Transfer System will } \\
\text { facilitate the interpretation of } \\
\text { Burkinabe certificates } \\
\text { abroad. }\end{array}$ & $18 \%$ & $7 \%$ & $22 \%$ & $53 \%$ \\
\hline
\end{tabular}

a The coding of responses for these negative items was reversed from 4 (disagree) to 1 (agree).

Preliminary treatments were applied to the data in order to establish and validate factors. Thus, the responses to the items in the interpretation and attitude measurement were recoded to a set of four scales, such as the one used for behavior measurement. Similarly, responses to negatively formulated items were reversed to make them comparable to responses to positively formulated items. Factor analysis helped establish 
three factors corresponding to the three dimensions evaluated: Interpretation (10 items, alpha = 0.72), Attitude (9 items, alpha = 0.79) and Behavior (8 items, alpha=0.71).

Analysis. In response to the first study question, descriptive analyses, statement by statement, provide a general picture of the respondents' assessment of items in the three dimensions. To make a judgment on this assessment, the following percentage scale was adopted: less than 40\% (negative trend), 40 to 59\% (neutral trend), 60\% or more (positive trend). To respond to the other two questions, inferential analyses based on the factor scores allow us to generalize some observed characteristics of respondents to the different subgroups of the populations they represent.

\section{Results}

The results are presented in three sections. In the first section, we draw a general portrait of the appropriation of the reform, according to the three dimensions of appropriation (interpretation, attitude, behavior) as perceived by students. In the second section, the results of regression analyses help understand the link between the appropriation of the reform and the sociodemographic characteristics of the students. In the third section we examine the relationships between the factors of appropriation using simple and multiple regression analyses.

\section{General Portrait of Reform Appropriation}

Interpretation of the reform. The examination of the percentages of agreement on what the students know and understand of the BMD reform through 10 items reveals that their knowledge of the Bologna Process is limited. Indeed, only 15 to $17 \%$ report agreeing that they are "aware of the adoption of the Bologna reform by the European countries" or "aware of the influence of [this] European reform on the BMD reform." Similarly, they are not familiar with the usefulness of the "Diploma Supplement" (36\%). On the other hand, 65\% agree with the statement "I understand semestrialization in the reform".

The reason for the adoption of the BMD reform by Burkina Faso is more or less known, as is the organization of study programs in course units, the operation of the BMD credit system, the academic and political objectives of the reform and its implications for how to study (44 to $52 \%$ ).

Attitude toward the reform. The degree of student adherence to the content and objectives of the reform is assessed through nine items. Examining students' responses with respect to their attitude toward the BMD reform (Table 2) shows that few (38\%) agree that the BMD system is more flexible and more acceptable than the former system. They somehow agree (43 to $55 \%)^{7}$ that things would go better without the reform, that it "represents a good strategy for higher education" in the country, that its adoption is necessary and "facilitates student and faculty exchanges between Burkina Faso and Europe". In contrast, a high percentage of students agree that the credit transfer system in the UEMOA area "will facilitate the interpretation of Burkinabe certificates abroad" (75\%) and that "the BMD reform goals are important" (70\%).

Behavior with regard to BMD reform. Examining the responses to each of the eight items relating to behavior toward the BMD reform (Table 3), it appears students showed little support for the reform since only $30 \%$ avoided criticizing it openly. Indeed, their

\footnotetext{
7 These figures represent the minimum and maximum scores for items E1 1, E15, E18 and E19 of Table 2.
} 
support for the BMD reform is mixed when we consider the proportion (44 to $54 \%)^{8}$ of those who say they have encouraged others to support the reform; have tried to help classmates overcome their resistance to change, to explain the benefits of the reform, to speak in favor of the reform; or have avoided open criticism of the reform. On the other hand, the trend is positive with regard to the proportion of those who have kept informed of the reform $(74 \%)$ or who have avoided opposing the reform in front of the authorities (66\%).

The second study question calls for going beyond the description of the general portrait of the appropriation of the BMD reform by students. In what follows, we present the results of more detailed analyses for certain particular subgroups of the student population.

\section{Appropriation of the Reform and Sociodemographic Characteristics}

We tested a set of multiple linear regression models tested to estimate the specific contribution of each sociodemographic variable to the variation in scores on the three factors of reform appropriation.

Interpretation of the reform. For this factor, the model accounts for $7 \%$ of the variation in scores ( $R^{2}$ adjusted), which is a small to medium-size effect. Other things being equal, the results show that the interpretation of the reform is associated significantly with gender and cohort, but not with the university attended or the study program. Being a female student is negatively associated $(\beta=-0.09, p=0.035)$ with the interpretation of the reform, i.e., when controlling the effect of the other variables, compared to male students, women report having less knowledge of the elements of the reform. Moreover, compared to students from the oldest cohorts (2009-2011), those from the last cohorts (2012-2013) show a better understanding of the reform $(\beta=0.17, p=0.002)$. Although more significant than the effect of gender, the cohort effect is nevertheless small.

Attitude toward the reform. The study program and cohort are significantly associated with variations in attitude toward the reform $\left(R_{\text {adjusted }}^{2}=0.07\right)$. Compared to students in arts, culture, humanities, legal and political sciences, those who study health sciences, technical and technological sciences show a more positive attitude toward the reform $(\beta=0.13, p=0.024)$. Similarly, if a student was admitted to the university in 2012 or 2013 , his or her adherence to the reform score is greater than that of the 2009-2011 cohorts $(\beta=0.19, p=0.001)$. As in the case of the evaluation of the interpretation of the reform, gender remains associated with the variation in attitudes of the respondents, but only marginally $(p=0.061)$, with female students showing a lower degree of adherence $(\beta=-$ o.08) than male students to the reform.

Behavior toward the reform. Taking sociodemographic characteristics into account explains $5 \%$ of the variation in behavior among students (Table 4), which represents a small to medium-size effect. The application of the multiple regression model reveals that the cohort is the only sociodemographic characteristic that is significantly associated with a variation in student behavior toward the reform $(p<0.05)$. Compared to students in the 2009-2011 cohorts, those admitted to the university in 2012 and 2013 show a greater commitment $(\beta=0.20)$ to the implementation of the reform. The effect of the cohort on student behavior, however, is small.

\footnotetext{
8 These figures represent the minimum and maximum scores for items E20, E2 1, E27, E28 and E30 of table 3.
} 
Table 3. Distribution of students according to the frequency of behavior with respect to the BMD reform $(n=522)$.

\begin{tabular}{clcccc}
\hline Num. & \multicolumn{1}{c}{ Items } & Not at all & $\begin{array}{c}\text { A } \\
\text { little }\end{array}$ & Enough & A lot \\
\hline E26 & I was openly critical of the reform & $30 \%$ & $32 \%$ & $16 \%$ & $22 \%$ \\
E20 & $\begin{array}{l}\text { I encouraged others to support the } \\
\text { reform. }\end{array}$ & $56 \%$ & $35 \%$ & $6 \%$ & $3 \%$ \\
E28 & $\begin{array}{l}\text { I tried to help classmates overcome } \\
\text { their resistance to change. }\end{array}$ & $52 \%$ & $28 \%$ & $11 \%$ & $9 \%$ \\
E21 & $\begin{array}{l}\text { I spoke in favor of the reform to } \\
\text { others. }\end{array}$ & $51 \%$ & $37 \%$ & $10 \%$ & $2 \%$ \\
E27 & $\begin{array}{l}\text { I tried to explain the advantages of } \\
\text { the reform to others. }\end{array}$ & $47 \%$ & $35 \%$ & $13 \%$ & $5 \%$ \\
E23 & $\begin{array}{l}\text { I have spoken openly against the reform. } \\
\text { I opposed the reform before the }\end{array}$ & $54 \%$ & $25 \%$ & $6 \%$ & $15 \%$ \\
E29 & $\begin{array}{l}\text { authorities. } \\
\text { I kept informed about the reform. }\end{array}$ & $26 \%$ & $44 \%$ & $20 \%$ & $10 \%$ \\
\hline
\end{tabular}

a The coding of responses for these negative items was reversed.

In summary, it should be noted that multiple regression analyses consistently show that the variation in individual scores on all three factors is associated with one's cohort. Attitude variation is also associated with study program, and gender predicts interpretation and, marginally, attitude when other sociodemographic characteristics are controlled. The response to the next question examines the relationships among the three factors of reform appropriation.

\section{Relationship Between Factors of Appropriation}

Individual scores in all three factors are positively correlated and statistically significant. Thus, the overall score on interpretation is strongly correlated to that of attitude $(r=0.52, p<0.01)$ and moderately to behavior $(r=0.46, p<0.01)$, while attitude and behavior are also strongly correlated $(r=0.55, p<0.01)$. These results show that the more the students state that they know or understand the BMD reform, the more they report that they adhere to it and the more they report actions to support its implementation.

Scores at all three factors vary according to the characteristics of the students, but by testing a multiple regression model (Table 5), it appears that taking into account the interpretation of the reform and the attitude of the students makes it possible to better predict their behavior. Indeed, this increases the percentage of explained variance by $11 \%$. The effects of both factors on behavior are small to medium and tend to negate the impact of sociodemographic characteristics, but the influence of attitude $(\beta=0.40)$ is much larger (one and a half times) than that of interpretation $(\beta=0.26)$. 
Table 4. Coefficients of linear regression of the sociodemographic and academic characteristics of students on behavior with regard to the BMD reform $(n=501)$.

\begin{tabular}{|c|c|c|c|}
\hline Parameters & $\begin{array}{c}\text { Standardized } \\
\text { coefficient } \\
\beta \\
\end{array}$ & $T$ & $p$ \\
\hline Constant & & 19.21 & 0.001 \\
\hline Gender (reference group: boys) & & & \\
\hline $\begin{array}{l}\text { Girls } \\
\text { University affiliation (reference group: } \\
\text { UO1) }\end{array}$ & -0.07 & -1.51 & 0.131 \\
\hline $\begin{array}{l}\text { Koudougou } \\
\text { Study program (reference group: Arts } \\
\text { and Communication/Humanities/Legal } \\
\text { and Political Sciences) }\end{array}$ & -0.01 & -0.17 & 0.868 \\
\hline $\begin{array}{l}\text { Pure and Applied Science/Life and } \\
\text { Earth Sciences }\end{array}$ & -0.07 & -1.36 & 0.173 \\
\hline $\begin{array}{l}\text { Health Science/Technical and } \\
\text { Technological Sciences }\end{array}$ & 0.03 & 0.59 & 0.556 \\
\hline $\begin{array}{l}\text { Economic Sciences and } \\
\text { Management/Education Sciences }\end{array}$ & 0.04 & 0.72 & 0.472 \\
\hline Cohort (reference group: 2009-2011) & & & \\
\hline $2001-2008$ & 0.03 & 0.59 & 0.557 \\
\hline $2012-2013$ & 0.20 & 3.53 & 0.001 \\
\hline
\end{tabular}

The results of the analysis of the questionnaire data made it possible to answer the three specific study questions. The following section summarizes the main points and discusses them in the light of the theoretical framework and the conclusions of similar research, particularly in sub-Saharan Africa.

\section{Discussion}

The theoretical framework identified three important dimensions in the process by which actors respond to change: interpretation of change, attitude toward change and behavior toward change. The description of these dimensions for students in the case of the BMD reform in Burkina Faso can be related to the conclusions of similar studies and suggest strategies for the effective implementation of the new university policy. The results of the first two questions will be discussed simultaneously. Those of the third question are discussed separately.

\section{Interpretation of the Reform}

The results obtained show that students are reasonably familiar with the BMD system as defined in the institutional documents, but much more so than previously, since André's study (2009) concluded that students and teachers in Burkina Faso were uninformed about the BMD system. Feudjio (2009) also noted in his study that few students in Cameroon were aware of the BMD reform. The situation has therefore improved for students in Burkina Faso. 
The survey found that the reform is better understood by male students and more recent cohorts of university students. Contrary to the conclusions of the Eta and Vubo study (2015), according to which the interpretation in Cameroon varies in relation to the local context, our results did not establish a variation of the interpretation of the reform by the students as a function of their university affiliation. The results of Eta and Vubo (2015) are probably related to the linguistic factor that characterizes higher education in Cameroon (an Anglophone system vs a Francophone system).

The degree of student knowledge of the BMD system suggests they should receive greater attention in information and training initiatives on the current reform, especially female students. However, the fact that the BMD reform is better known among students newly admitted to university indicates a positive trend in the interpretation of the reform that will eventually affect the attitudes of the actors.

Table 5. Coefficients of linear regression of sociodemographic and academic characteristics of students, interpretation and behavioral attitude toward BMD reform $(n=483)$.

\begin{tabular}{|c|c|c|c|}
\hline Parameters & $\begin{array}{c}\text { Standardized } \\
\text { coefficient } \\
\beta\end{array}$ & $T$ & $p$ \\
\hline Constant & & 7.41 & 0.001 \\
\hline \multicolumn{4}{|l|}{ Gender (reference group: Boys) } \\
\hline Girls & 0.00 & 0.12 & 0.903 \\
\hline \multicolumn{4}{|l|}{ University affiliation (reference group: UO1) } \\
\hline \multicolumn{4}{|l|}{$\begin{array}{l}\text { Study program (reference group: Arts and } \\
\text { Communication/Humanities/Legal and } \\
\text { Political Sciences) }\end{array}$} \\
\hline $\begin{array}{l}\text { Pure and Applied Science/Life and Earth } \\
\text { Sciences }\end{array}$ & -0.05 & -1.12 & 0.261 \\
\hline $\begin{array}{l}\text { Health Science/Technical and } \\
\text { Technological Sciences }\end{array}$ & -0.04 & -0.82 & 0.415 \\
\hline $\begin{array}{l}\text { Economic Sciences and } \\
\text { Management/Education Sciences }\end{array}$ & 0.08 & 1.75 & 0.080 \\
\hline \multicolumn{4}{|l|}{ Cohort (reference group 2009-2011) } \\
\hline $2001-2008$ & 0.01 & 0.14 & 0.885 \\
\hline 2012-2013 & 0.08 & 1.59 & 0.112 \\
\hline Interpretation & 0.26 & 5.96 & 0.001 \\
\hline Attitude & 0.40 & 8.99 & 0.001 \\
\hline \multicolumn{4}{|c|}{$\Delta R^{2}=0.11, R_{\text {adjusted }}^{2}=0.34$} \\
\hline
\end{tabular}

\section{Attitude Toward Reform}

The analyses indicate that the students express a moderate adherence to the reform, in the same vein as the conclusions of Goudiaby, which in 2009 revealed a less enthusiastic adherence among the students in Senegal. The attitude of Burkina Faso's students has also changed, since the study by André (2009) revealed an indifference of these actors toward 
the reform at the beginning of its implementation. However, the attitude toward the reform is more positive for students admitted in 2012 and 2013 and for male students. As well, students in health sciences, technical and technological sciences (HS/TTS) show greater support for the reform than their colleagues in letters, the arts, culture, humanities, and legal and political sciences (LAC/H/LPS). This latter result is consistent with the work of Becher and Trowler (2001), according to which the reaction of academic institutions to innovation depends on the culture of the disciplines. In Burkina Faso, the internationally competitive nature of the first group (HS/TTS) ("hard" and applied disciplines) is greater than that of the second group ("soft" and pure disciplines). According to the findings of the study by Hoffman et al. (2008) conducted in Finland, academic units whose competitive horizon is global in scope have welcomed the Bologna Process more favorably than more locally competitive departments such as history and sociology.

For a better implementation of the BMD reform, the results suggest paying particular attention to female students and those in disciplines whose competitive horizon is more limited (letters, the arts, culture, humanities, legal and political sciences). The trend toward a lower level of adherence to the reform observed in these groups could jeopardize the positive evolution linked to the cohort effect.

\section{Behavior Towards to the Reform}

The behavior of students toward the reform is associated with the cohort, and positively for the latest admitted to university, all other things being equal. This positive evolution in the support of new students to the BMD reform is probably associated with their adherence noted above, their lived experiences and the resulting concerns. In general, students report actions in support of the BMD reform, although some resistance has been observed, probably in relation to the conditions of its implementation, as Diop (2016) noted for Senegal. This situation differs from that of the European countries where, according to Crosier and Parvela (2013), the reform has met "widespread and strong resistance" (p. 68) among students and teachers because it is associated in these actors' mind with a neoliberal program, synonymous with privatization and free trade and with harmful consequences, in their view.

The influence of actors' concerns on their behaviors toward change was highlighted by Meunier (2010); which recommends that particular attention be paid to the concerns that students express throughout the cycles of the BMD reform. Indeed, students' concerns about the impact of this new policy on their jobs, their status and their work environment could encourage or resurrect resistance behaviors if they are not resolved.

\section{Relationship Between the Three Dimensions of Appropriation}

The analyses allowed us to establish a statistically significant correlation between the students' interpretation of the BMD reform and their attitude and behavior toward it. The students' interpretation of the reform is more strongly associated with their attitude than is their cohort. Similarly, attitude rather than interpretation, excluding sociodemographic variables, is strongly related to the behavior adopted by the students toward the reform. This result is consistent with the conclusions of Meunier's study (2010) that the attitude toward change acts as a mediating variable of the actors' concerns and better explains their support and resistance behaviors.

The results thus show that the theoretical coherence between the dimensions of appropriation has an empirical basis. The more a student knows and understands the reform, the more he or she adheres to it and the more he or she supports its 
implementation. Conversely, the less a student knows and understands the reform, the less he or she adheres to it and the more he or she resists it. Thus, as for the appropriation of technological or management tools (de Vaujany, 2006), the appropriation of a policy is a complex process, an integrated and dynamic set of interdependent cognitive, affective and behavioral mechanisms.

The coherence and dynamic nature of the appropriation components of the BMD reform recommend in particular that government and academic authorities pay attention to students' interpretation of the reform. Indeed, a good knowledge and understanding of the reform favors their adherence and their support for its implementation.

\section{Conclusion}

Given the importance of the role played by the actors in the implementation of a public policy, this study aimed to examine the involvement of students in the implementation of the BMD reform in Burkina Faso. In general, there is a positive correlation between students' interpretation of the reform and their attitude and behavior toward the BMD system. The results highlight that the appropriation of the reform among students varies according to their sociodemographic characteristics, particularly their cohort. But the definition of the cohort used in this research constitutes one of its limitations. In effect, inclusion in a cohort is based on the year of secondary school graduation and not on the year of admission to the university program. In addition, the non-longitudinal design does not sufficiently highlight the evolving and dynamic nature of appropriation and the study did not take into account the growing private sector, which accounts for a quarter of higher education in Burkina Faso. However, the results obtained suggest practical recommendations for better steering of the implementation of university reforms, and the limitations identified indicate future lines of research, such as the study of the trajectory of the BMD reform in private-sector higher education.

\section{References}

Albarracín, D., Johnson, B. T., Zanna, M. P. and Kumkale, G. T. (2005). Attitudes: Introduction and scope. In D. Albarracín, B. T. Johnson and M. P. Zanna (eds.), The Handbook of Attitudes, (pp. 3-19). Mahwah, NJ: Erlbaum.

Allègre, C., Berlinguer, L., Blackstone, T. and Rüttgers, J. (1998). Sorbonne Joint Declaration. Joint declaration on harmonisation of the architecture of the European higher education system. Paris, at the Sorbonne, May 25. Retrieved from https://media.ehea.info/file/1998_Sorbonne/61/2/1998_Sorbonne_Declaration_E nglish_552612.pdf

Altbach, P. G. (2007). Globalization and the university: Realities in an unequal world. In J. J. F. Forest and P. G. Altbach (eds.), International Handbook of Higher Education (pp. 121-139). doi:10.1007/978-1-4020-4012-2-8

André, G. (2009). Le campus universitaire de Ouagadougou: de l'injonction globale à adopter le LMD aux réalités locales. In J. E. Charlier, S. Croché and A. K. Ndoye (eds.), Les universités africaines francophones face au LMD: les effets du processus de Bologne sur l'enseignement supérieur au-delà des frontières de l'Europe (pp. 265-281). Louvain-la-Neuve, Belgium: Academia-Bruylant.

Association des universités africaines. (2008). Guide de formation du LMD à l'usage des institutions d'enseignement supérieur d'Afrique francophone. Accra, Ghana: AUA. 
Retreived from http://curricula-uemoa.esg.uqam.ca/upload/files/guide-formationLMD.pdf

Baillette, P. and Kimble, C. (2008). The Concept of appropriation as a heuristic for conceptualising the relationship between technology, people and organisations. Communication at the 13th UKAIS Conference, Bournemouth, United Kingdom.

Bareil, C. (2008). Démystifier la résistance au changement: questions, constats et implications sur l'expérience du changement. Télescope, (pp. 89-105).

Becher, T. and Trowler, M. (2001). Academic tribes and territories: Intellectual enquiry and the cultures of disciplines ( $2^{\text {nd }}$ ed.). Ballmoor, United Kingdom: Society for Research into Higher Education.

Bianchi, J. and Kouloumdjian, M. F. (1986). Le concept d'appropriation. In A. Laulan, J. Bianchi and M. F. Kouloumdjian, L'espace social de la communication (pp. 143-149). Paris, France: Retz/CNRS.

Bianchini, P. and Korbéogo, G. (2008). Le syndicalisme étudiant, des origines à nos jours: un acteur permanent dans l'évolution sociopolitique du Burkina Faso. Journal of Higher Education in Africa/Revue de l'enseignement supérieur en Afrique, 6(2\&3), 33-60.

Brewer, J. (2003). Interpretation. In R. L. Miller and J. D. Brewer (eds.), The A-Z of social research: A dictionary of key social science research concepts (pp. 165-166). Sage Publications, Ltd. doi: 10.4135/9780857020024.n56

Callon, M. (1984). Éléments pour une sociologie de la traduction: la domestication des coquilles Saints-Jacques et des marins pêcheurs dans la baie de Saint-Brieuc. L'Année sociologique, 36, 169-207.

Charlier, J. E. and Croché, S. (2010). L’inéluctable ajustement des universités africaines au processus de Bologne. Revue française de pédagogie, 172, 77-84.

Charlier, J. E. and Croché, S. (2012). L’influence normative du processus de Bologne sur les universités africaines francophones. Éducation et sociétés, 29(1), 87-102. doi: $10.3917 /$ es.029.0087

Charlier, J. E., Croché, S. and Ndoye, A. K. (2009) (eds.). Les universités africaines francophones face au LMD: les effets du processus de Bologne sur l'enseignement supérieur au-delà des frontières de l'Europe. Louvain-la-Neuve, Belgium: Academia-Bruylant.

Communauté économique et monétaire des États de l'Afrique centrale. (2006). Directive $N^{\circ}$ O1/06-UEAC-019-CM-14 portant application du système LMD (Licence, Master, Doctorat) dans les universités et établissements d'enseignement supérieur de l'espace CEMAC, March 11. Bata, Equatorial Guinea. Retrieved from https://www.izf.net/upload/document/JournalOfficiel/cemac2006/Directive_02_0 6_UEAC_019_CM_14.pdf

Crosier, D. and Parveva, T. (2013). The Bologna Process: Its impact on higher education development in Europe and beyond. Paris, France: International Institute for Educational Planning.

Datnow, A. and Park, V. (2009). Conceptualizing policy implementation: Large-scale reform in an era of complexity. In G. Sykes, B. Schneider and D. N. Plank (eds.), Handbook of Education Policy Research (pp. 348-361). Routledge.

DeSanctis, G. and Poole, M. S. (1994). Capturing the complexity in advanced technology use: Adaptative structuration theory. Organization Science, 5(2), 121-147.

De Vaujany, F. X. (2006). Pour une théorie de l'appropriation des outils de gestion: vers un dépassement de l'opposition conception-usage. Management et Avenir, 3(9), 109-126. doi:10.3917/mav.009.0109 
Deniger, M. A. (2012). La gestion et l'appropriation du changement en éducation. Éducation et francophonie, 4O(1), 1-11.

Diop, B. (2016). Réformer l'enseignement supérieur au Sénégal: conception, mise en ceuvre et conséquences du système LMD (unpublished doctoral thesis). Université de Genève, Switzerland.

Doh, P. S. (2007). Harmonization challenges in higher education: Case of the French and British bicultural system in Cameroon (Master's dissertation, University of Tampere). Retrieved from http://tampub.uta.fi/handle/10024/78117

Eagly, A. and Chaiken, S. (1993). The Psychology of attitudes. Belmont, CA: Thomson Wadsworth.

Eta, E. A. (2015). Policy borrowing and transfer, and policy convergence: Justifications for the adoption of the Bologna Process in the CEMAC region and the Cameroonian higher education system through the LMD reform. Comparative Education, 51(2), 161-178. doi: 10.1080/03050068.2014.941174

Eta, E. A. and Vubo, E. Y. (2015). Global references, local translation: Adaptation of the Bologna Process degree structure and credit system at universities in Cameroon. Globalisation, Societies and Education, 14(4), 492-512. doi:10.1080/14767724.2015.1077102

European Ministers of Education. (1999). The Bologna Declaration of 19 June 1999. Joint declaration of the European Ministers of Education. Retrieved from https://www.eurashe.eu/library/modernising-phe/Bologna_1999_BolognaDeclaration.pdf

Fishbein, M. and Ajzen, I. (2010). Predicting and changing behavior: The reasoned action approach. New York, NY: Taylor \& Francis.

Gabas, J. J. (2003). Acteurs et politiques publiques. Mondes en développement, 124(4), 33-47. doi:10.3917/med.124.0033

Giddens, A. (1984). The constitution of society: Introduction of the theory of structuration. Berkeley, CA: University of California Press.

Goudiaby, J. A. (2009). Le Sénégal dans son appropriation de la Réforme LMD: déclinaison locale d'une réforme globale. Journal of Higher Education in Africa/Revue de l'enseignement supérieur en Afrique, 7(1\&2), 79-93.

Hassenteufel, P. (2011). Sociologie politique: l'action publique (2nd ed.). Paris, France: Armand Colin.

Herscovitch, L. and Meyer, J. P. (2002). Commitment to organizational change: Extension of a three-component model. Journal of Applied Psychology, 87(3), 474-487. doi: $10.1037 / 0021-9010.87 .3 .474$

Hoffman, D. M., Välimaa, J. and Huusko, M. (2008). The Bologna Process in academic basic units: Finnish universities and competitive horizons. Cultural Perspectives on Higher Education (pp. 227-243). doi:10.1007/978-1-4020-6604-7_15

Idiata, D. F. (2006). L'Afrique dans le système LMD-licence-master-doctorat: la réforme de toutes les révolutions: le cas du Gabon. Paris, France: Éditions L’Harmattan.

Jacquemot, P. (2007). Harmonisation et appropriation de l'aide. Commentaires autour de l'expérience du Ghana. Afrique Contemporaine, 223, 161-191.

Khelfaoui, H. (2009). Le processus de Bologne en Afrique: globalisation ou retour à la "situation coloniale"? Journal of Higher Education in Africal Revue de l'enseignement supérieur en Afrique, 7(1\&2), 1-20. 
Ki-Zerbo, J. (ed.) (1992). La natte des autres: pour un développement endogène en Afrique. Conference proceedings of the Centre de recherche pour le développement endogène (CRDE), Bamako 1989. Dakar, Senegal: CODESRIA.

Lascoumes, P. and Le Galès, P. (2012). Sociologie de l'action publique (2 ${ }^{\text {nd }}$ ed.). Paris France: A. Colin.

Massard, N. (2007). Le processus d'appropriation d'un progiciel de gestion intégré par l'utilisateur final: vers une compréhension des facteurs d'influence menant aux bonnes pratiques attendues (unpublished doctoral thesis). CRET-LOG, Université Aix Marseille II.

Mesquita, D., Fernandes, S., Pereira, D., Flores, M. A. and Filipe Costa, M. F. (2011). Bologna Process and its implications: What does the research literature tell us? Presentation to the 55th World Assembly of the International Council on Education for Teaching (ICET), Glasgow, Scotland. Retrieved from http://repositorium.sdum.uminho.pt/bitstream/1822/15887/1/2011_ICET_bolog na MESQUITA PEREIRA FERNANDES.pdf

Meunier, S. (2010). Le changement organisationnel: la prédiction des comportements de soutien et de résistance par le biais des préoccupations (unpublished doctoral thesis). Université de Montréal, Canada.

Michelik, F. (2008). La relation attitude-comportement: un état des lieux. Éthique et économique, 6(1). Retrieved from http://hdl.handle.net/1866/3417

Ministère de l'Enseignement supérieur, de la recherche scientifique et de l'innovation. (2016). Annuaire statistique de l'enseignement supérieur 2015-2016. Ouagadougou, Burkina Faso: Direction générale des études et statistiques sectorielles.

Mngo, Z. Y. (2011). Instructors' perceptions of the Bologna model of higher education reform in Cameroon (Doctoral thesis, Andrews University). Retrieved from http://digitalcommons.andrews.edu/dissertations/584/

Ndior, B. (2013). Les universités publiques à l'ère de la professionnalisation des études dans la réforme LMD. Le cas du Sénégal (unpublished doctoral thesis). Université de Strasbourg, France.

Nisbett, R. E. and Miyamoto, Y. (2005). The influence of culture: Holistic versus analytic perception. Trends in cognitive sciences, 9(10), 467-473.

Olson, J. M. and Stone, J. (2005). The influence of behavior on attitudes. In D. Albarracín, B. T. Johnson and M. P. Zanna (eds.), The Handbook of Attitudes (pp. 223-272). Mahwah, NJ: Erlbaum.

Orth, M. S. (2002). Factors related to resistance and support of organizational change (unpublished doctoral thesis). Colorado State University, CO.

Porras, J. I. and Hoffer, S. J. (1986). Common behaviour changes in successful organization development efforts. Journal of Applied Behavioural Science, 22(4), 477-494.

Prislin, R. and Wood, W. (2005). Social influence in attitudes and attitude change. In D. Albarracín, B. T. Johnson and M. P. Zanna (eds.), The Handbook of Attitudes (pp. 671 706). Mahwah, NJ: Erlbaum.

Proulx, S. (2002). Trajectoires d'usages des technologies de communication: les formes d'appropriation d'une culture numérique comme enjeu d'une société du savoir. Annales des Télécommunications, 57, 180-189.

Ravinet, P. (2009). Comment le processus de Bologne a-t-il commencé? La formulation de la vision de l'espace européen d'enseignement supérieur en 1998. Éducation et sociétés, 24(2), 29-44. doi:10.3917/es.024.0029 
Roux, A. (2007). De l'usage à la pratique: les processus d'appropriation. Emprunts à la théorie de la structuration et empreinte du chercheur. Communication et organisation, 31. Retreived from http://communicationorganisation.revues.org/168

Saliba-Couture, C. (2011). L'appropriation et la Déclaration de Paris: un discours convaincant, mais en sommes-nous convaincus? Canadian Journal of Development Studies/Revue canadienne d'études du développement, 32(2), 180-195. doi: 10.1080/02255189.2011.596030

Sanou, F. and Charmillot, M. (2010). L'éducation supérieure dans les politiques éducatives en Afrique subsaharienne. Le cas du Burkina Faso. In A. Akkari and J. P. Payet (eds.), Transformations des systèmes éducatifs dans les pays du Sud. Entre globalisation et diversification (pp. 119-145). Brussels, Belgium: De Boeck.

Scott, J. and Marshall, G. (2009). A dictionary of sociology ( $3^{\text {rd }}$ ed.). Oxford, United Kingdom: Oxford University Press.

Sory, I. (2012). L'Université de Ouagadougou: Territoire de la contestation et de la répression des étudiants. Revue de l'enseignement supérieur en Afrique, 1O(1), 171-194.

Tight, M. (2004). Research into higher education: An a-theoretical community of practice? Higher Education Research E Development, 23(4), 395-411.

Union économique et monétaire ouest-africaine. (2007). Directive $\mathrm{N}^{\circ} 03 / 2007 / C M / U E M O A$ portant adoption du système Licence, Master, Doctorat (LMD) dans les universités et établissements d'enseignement supérieur au sein de l'UEMOA, July 4. Dakar, Senegal. Retreived from http://www.uemoa.int/sites/default/files/bibliotheque/directive_03-2007-cmuemoa portant adoption lmd.pdf

Vaidis, D. (2006). Attitude et comportement dans le rapport cause-effet: quand l'attitude détermine l'acte et quand l'acte détermine l'attitude. Linx. Revue des linguistes de l'université Paris $X$ Nanterre, 54, 103-111. doi:10.4000/linx.507

Willige, J. (2003). Students en route to Europe: The 2003 student survey on the acceptance of the Bologna Process. HIS Higher Education Information System, Hannover. Retrieved from https://hisbus.his.de/hisbus/docs/hisbus-bologna-eng.pdf

Woldegiorgis, E. T., Jonck, P. and Goujon A. (2015). Regional higher education reform initiatives in Africa: A comparative analysis with the Bologna Process. International Journal of Higher Education, 4(1), 241-253. doi:10.5430/ijhe.v4n 1p24 1

\section{About the Authors}

Pascal Ramdé is an assistant professor and secretary-general of the Université Saint Thomas d'Aquin in Ouagadougou, Burkina Faso. His research interests focus on educational policies, higher education and the training of school administrators. His publications concern the evaluation of the implementation of the Bologna Process in West African universities and the link between school leadership and school climate. His teaching focuses mainly on the areas of educational policy evaluation and values education.

Pierre Lapointe is a professor in the Department of Educational Administration and Foundations at the Université de Montréal. His research addresses issues related to school principal preparation, change and reform, and student achievement.

Martial Dembélé is an associate professor in the Faculty of Education at the Université de Montréal, which he joined in 2005 after co-directing the Paul-Gérin-Lajoie Interuniversity Center for International Development in Education at the Université du Québec à Montreal. His teaching, research and consultancy have been in the areas of school 
improvement, the teaching profession in developing countries, and more recently accountability in education. He is the co-author, with Jack Schwille, of Global Perspectives on Teacher Learning: Improving Policy and Practice, published by UNESCO IIEP in 2007. His recent publications include, among others, More and Better Teachers for Quality Education for All: Identity and Motivation, Systems and Support (Kirk, Dembélé \& Baxter, 2013); Pedagogical orientations and foundations in the discourse emanating from the OECD's TALIS initiative (Cerqua, Gauthier \& Dembélé, 2017), and two special issues on the teaching profession in Sub-Saharan Africa (Dembélé, Sirois \& Anne, 2017; Dembélé \& Sirois, 2018). 